\section{Studia}

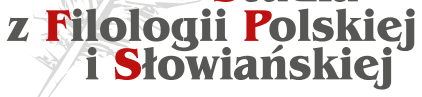

DOI: $10.11649 /$ sfps.1735
Studia z Filologii Polskiej i Słowiańskiej, 54

Warszawa 2019

Article No. 1735

Citation:

Сегін, Л. В. (2019). Префіксальні дієслова зі значенням «переміщення вгору» в структурі словотвірної парадигми дієслова в українській мові. Studia $z$ Filologii Polskiej i Słowiańskiej, 54. https://doi.org/10.11649/sfps.1735

Sehin, L. V. (2019). Prefiksal'ni diieslova zi znachenniam "peremishchennia vhoru" v strukturi slovotvirnoï paradyhmy diieslova v ukraïns'kiı̌ movi. Studia z Filologii Polskiej i Stowiańskiej, 54. https://doi.org/10.11649/sfps.1735

\author{
Любомир В. Сегін
}

(Донбаський державний педагогічний університет,

Слов'янськ)

\title{
Префіксальні дієслова зі значенням «переміщення вгору» в структурі словотвірної парадигми дієслова в українській мові
}

У словотворі слов'янських мов кінця XX - початку XXI ст. набуває все більшої актуальності розвиток основоцентричного напряму, в основі якого лежить функціональне навантаження твірних слів різної частиномовної належності. Такий підхід дає змогу виявити й описати словотвірний потенціал різних класів слів, проаналізувати особливості сукупностей дериватів, об'єднаних твірною основою й виявити мовні та позамовні чинники, які детермінують реалізацію твірними основами дериваційних можливостей.

Підгрунтя основоцентризму в дериватології заклав I. I. Ковалик, який звернув увагу на те, що

[...] не маємо в ділянці вчення про словотвір ні однієї спеціальної праці, в якій була б охарактеризована вся система будови словотвору даної мови з погляду структури словотворчих основ. А втім такий аспект вивчення

This is an Open Access article distributed under the terms of the Creative Commons Attribution 3.0 PL License (creativecommons.org/licenses/by/3.0/pl/), which permits redistribution, commercial and non-commercial, provided that the article is properly cited. (c) The Author(s) 2019.

Publisher: Institute of Slavic Studies, Polish Academy of Sciences

[Wydawca: Instytut Slawistyki Polskiej Akademii Nauk] 
системи словотвору даної мови допоміг би краще зрозуміти словотворчі факти й дав би надійні підстави зробити далеко глибші висновки й узагальнення з теоретичних питань учення про словотвір (Ковалик, 1964, сс. 43-44).

В україністиці одна з перших розвинула цю думку Н. Ф. Клименко, яка у своїй праці на матеріалі дієслів переконливо розкрила, як семантика твірного слова реалізується в девербативах різних частин мови (Клименко, Пещак, \& Савченко, 1982, сс. 99-192). Концепцію основоцентризму поглибили і послідовно застосували Є. А. Карпіловська, М. І. Голянич, М. П. Лесюк, В. В. Грещук, 3. О. Валюх та ін., праці яких стали поштовхом до дослідження словотвірного потенціалу, який може виявлятися на рівні комплексних словотвірних одиниць. На сьогодні в україністиці $\epsilon$ напрацювання на кожному із цих рівнів (О. П. Кушлик, Л. І. Коржик, О. Д. Микитин, С. П. Гірняк, Р. О. Барчук та ін.).

Останнім часом дериватологи наголошують на тому, що специфічною комплексною одиницею класифікації й аналізу словотвірного матеріалу, що уможливлює вияв системної організації словотвору, є словотвірна парадигма (далі: СП), яку трактують як сукупність дериватів, що мотивовані тим самим твірним і перебувають на одному ступені похідності (Грещук, Бачкур, Джочка, \& Пославська, 2007, с. 10; Земская, 1992, с. 17; Клименко, 2004, с. 619 та ін.). На думку дослідників, СП є найкращим шляхом дослідження дериваційного потенціалу лексико-семантичних груп слів різних частин мови (Земская, 1992, с. 25), здатна фіксувати дериваційний потенціал слова більш типізовано, ніж гніздо (Бузашиова, 1987, с. 19), є більш оптимальною і операбельною (Грещук та ін., 2007, с. 24). Особливу цікавість з цього погляду представляє вивчення дериваційного потенціалу дієслів як центральної частини мови, в якому закладено великі можливості. В українському мовознавстві $€$ низка лінгвістичних досліджень, у яких проаналізовано словотвірний потенціал непохідних дієслів (І. Ф. Джочка, Н. М. Пославська, Р. В. Познанський, Н. В. Адамець). Проте, незважаючи на значні напрацювання в цій царині, залишаються питання, які потребують подальшого дослідження. Одним із таких питань є вивчення словотвірного потенціалу похідних дієслів. Наразі проаналізовано в цьому ракурсі префіксальні дієслова української мови іменникового, прикметникового і звуконаслідувального походження (О. П. Кушлик), окремі групи префіксальних дієслів динамічної просторової локалізо- 
ваності (ДПЛ) (Л. В. Сегін). Префіксальні дієслова ДПЛ зі значенням «переміщення вгору» не були предметом спеціального дослідження з позицій основоцентричної дериватології.

У пропонованій розвідці розглянемо словотвірний потенціал дієслів зі значенням «переміщення вгору», зокрема проаналізуємо склад та структурно-семантичні особливості твірних префіксальних дієслів, визначимо структурну типологію досліджуваних девербативів, окреслимо континуум словотвірних значень, реалізованих похідними від префіксальних дієслів і їх кількісні параметри та встановимо набір дериваційних засобів їх реалізації.

Матеріалом для дослідження слугували девербативи української мови, отримані методом суцільної вибірки з найавторитетніших джерел (СУМ, 1970-1980; СУМГ, 1996; ВТССУМ, 2001; ВЗОССУЛ, 2003). Обсяг вибірки склав 240 твірних та похідних дериватів.

У сучасній українській мові функціонує значна група префіксальних дієслів, які означають переміщення у вертикальній площині. Вертикальна орієнтація руху, як відомо, відбувається у двох напрямках згори донизу і знизу догори. Дієслова кожної з цих груп мають свої особливості, пов'язані з їхньою семантикою, характером мотиваційних відношень, засобами, за допомогою яких утворені ці деривати тощо. У нашому дослідженні склад лексико-семантичної групи визначаємо на основі аналізу дефініцій слів у тлумачних словниках української мови. До цієї групи відносимо префіксальні дієслова, в лексичному значенні яких наявна вказівка на динамічний рух, що спрямований вгору. В результаті опрацювання лексичних значень слів у тлумачних словниках української мови можна стверджувати, що група префіксальних дієслів зі значенням «переміщення вгору» нараховує 60 дериватів: ви́бігти / вибіга́ти3; вивезти / виво́зитиза; ви́дертися, ви́дратися / видира́тися2; вйїхати / виїздити, виїжджа́тиз; залізти / зала́зити1, заліза́ти1; злетіти / злітати 1 ; підкинути / підкидати, підкидувати1; підскочити / підскакувати ; підвищити / підвищувати; підняти, підійняти / піднімати, підіймати1,a, 2,a,6,в,3, а та ін.

Під час вивчення комплексних одиниць варто враховувати семантичний і словотвірний аспекти. Слушною є думка С. О. Соколової про важливість послідовного врахування семантики під час словотвірного аналізу для дієслова, оскільки йому властива найбільша багатозначність серед самостійних частин мови (Соколова, 2003, с. 7). Як відомо, бага- 
тозначна дієслівна лексема є сукупністю лексико-семантичних варіантів (далі: ЛСВ). На думку дослідників, аналіз матеріалу на рівні ЛСВ, який дає змогу простежити реалізацію семантичного потенціалу твірного в похідних та визначити чинники, які впливають на можливості засвоєння семантичного обсягу твірного похідним, $є$ найперспективнішим (Дідух, 2004, с. 159; Соколова, 2003, с. 7). При цьому в ролі окремого ЛСВ пропонують розглядати також і відтінки значення (Клименко та ін., 1982, c. 61; Пославська, 2011, с. 82). Поділяємо і твердження щодо того, що при врахуванні семантики під час установлення словотвірних відношень слід співвідносити в цьому плані не лексеми, а різні значення багатозначних префіксальних дієслів і похідних іншої частиномовної належності з різними ЛСВ твірних дієслів (Соколова, 2003, с. 7).

Таблиця 1. Розподіл членів СП дієслова підняти, підійняти / nіднімати, nідіймати за ЛСВ на позначення динамічного руху та частиномовними блоками

\begin{tabular}{|c|c|c|c|}
\hline \multirow{2}{*}{$\begin{array}{c}\text { ЛСВ твірного } \\
\text { дієслова }\end{array}$} & \multicolumn{3}{|c|}{ Блоки СП } \\
\hline & Субстантивний & Ад'єктивний & Вербальний \\
\hline $\begin{array}{l}\text { 1. Нахилив- } \\
\text { шись, брати, } \\
\text { підбирати } \\
\text { з землі, під- } \\
\text { логи, знизу }\end{array}$ & $\begin{array}{l}\text { піднімання, підій- } \\
\text { мання, підняттяя } \\
\text { підйом1 }\end{array}$ & $\begin{array}{l}\text { піднімальниц̆, підій- } \\
\text { мальний, підйом- } \\
\text { ний1а, піднятиц̆, } \\
\text { підійнятий, підніма- } \\
\text { ючий }\end{array}$ & $\begin{array}{l}\text { nопіднімати, попі- } \\
\text { діймати, піднятися, } \\
\text { підійнятися / підні- } \\
\text { матися, підійматися }\end{array}$ \\
\hline $\begin{array}{l}\text { a) переміщати } \\
\text { знизу вгору, } \\
\text { витягаючи } \\
\text { з води, з загли- } \\
\text { бини }\end{array}$ & $\begin{array}{l}\text { піднімання, підій- } \\
\text { мання, підняття1, } \\
\text { підйом1, піднімач } \\
\text { (мед.), суднопідні- } \\
\text { мання, суднопідій- } \\
\text { мання, суднопідіймач }\end{array}$ & $\begin{array}{l}\text { піднімальний, } \\
\text { підіймальниц̆, під- } \\
\breve{u ̈ о м н и и ̆ l а, ~ п і д н я-~} \\
\text { тиц̆, підійнятий, } \\
\text { суднопідіймальниц̆, } \\
\text { суднопіднімальний, } \\
\text { піднімаючиц }\end{array}$ & $\begin{array}{l}\text { попіднімати, попі- } \\
\text { діймати, піднятися, } \\
\text { підійнятися / підні- } \\
\text { матися, підійматися }\end{array}$ \\
\hline $\begin{array}{l}\text { 2. Узявши, } \\
\text { переміщати } \\
\text { (підносити і т. } \\
\text { ін.) знизу вгору }\end{array}$ & $\begin{array}{l}\text { піднімання, підій- } \\
\text { мання, підняття } 1 \text {, } \\
\text { підйом1, підйом2, } \\
\text { сінопідіймач, сіно- } \\
\text { піднімач, стеблепід- } \\
\text { німач }\end{array}$ & $\begin{array}{l}\text { піднімальниц̆, підій- } \\
\text { мальниц̆, підйом- } \\
\text { ний1а, піднятици, } \\
\text { підійнятиц̆, підніма- } \\
\text { ючий }\end{array}$ & $\begin{array}{l}\text { попіднімати, попі- } \\
\text { діймати, піднятися, } \\
\text { підійнятися / підні- } \\
\text { матися, підійматися }\end{array}$ \\
\hline $\begin{array}{l}\text { а) переміщати } \\
\text { що-небудь } \\
\text { угору для } \\
\text { виконання } \\
\text { якоїсь дії }\end{array}$ & $\begin{array}{l}\text { піднімання, підій- } \\
\text { мання, підняття } 1 \text {, } \\
\text { підйом1, піднімач } \\
\text { (мед.), сінопідіймач, } \\
\text { сінопіднімач, стебле- } \\
\text { піднімач }\end{array}$ & $\begin{array}{l}\text { піднімальниц̆, підій- } \\
\text { мальний, підйом- } \\
\text { ний1а, піднятий, } \\
\text { підійнятий, підніма- } \\
\text { ючий }\end{array}$ & $\begin{array}{l}\text { попіднімати, попі- } \\
\text { діймати, піднятися, } \\
\text { підійнятися / підні- } \\
\text { матися, підійматися }\end{array}$ \\
\hline
\end{tabular}




\begin{tabular}{|c|c|c|c|}
\hline \multirow{2}{*}{$\begin{array}{c}\text { ЛСВ твірного } \\
\text { дієслова }\end{array}$} & \multicolumn{3}{|c|}{ Блоки СП } \\
\hline & Субстантивний & Ад'єктивний & Вербальний \\
\hline $\begin{array}{l}\text { б) відривати } \\
\text { від землі, пере- } \\
\text { борюючи силу } \\
\text { тяжіння }\end{array}$ & $\begin{array}{l}\text { піднімання, підій- } \\
\text { мання, підняття } 1 \text {, } \\
\text { підйом1, сінопідій- } \\
\text { мач, сінопіднімач, } \\
\text { стеблепіднімач }\end{array}$ & $\begin{array}{l}\text { піднімальниц̆, підій- } \\
\text { мальний, підйом- } \\
\text { ний1а, піднятици, } \\
\text { підійнятиц̆, підніма- } \\
\text { ючий }\end{array}$ & $\begin{array}{l}\text { попіднімати, попі- } \\
\text { діймати, піднятися, } \\
\text { підійнятися / підні- } \\
\text { матися, підійматися }\end{array}$ \\
\hline $\begin{array}{l}\text { в) знімаючи } \\
\text { що-небудь із } \\
\text { чогось, пере- } \\
\text { міщати вгору, } \\
\text { вбік }\end{array}$ & $\begin{array}{l}\text { піднімання, підій- } \\
\text { мання, підняття1, } \\
\text { підйом } 1\end{array}$ & $\begin{array}{l}\text { піднімальниц̆, підій- } \\
\text { мальний, підйом- } \\
\text { ний1а, піднятий, } \\
\text { підійнятиц̆, підніма- } \\
\text { ючий }\end{array}$ & $\begin{array}{l}\text { попіднімати, попі- } \\
\text { діймати, піднятися, } \\
\text { підійнятися / підні- } \\
\text { матися, підійматися }\end{array}$ \\
\hline $\begin{array}{l}\text { 3. Переміщати } \\
\text { на вище місце, } \\
\text { залишаючи } \\
\text { там }\end{array}$ & $\begin{array}{l}\text { піднімання, підій- } \\
\text { мання, підняття } 1 \text {, } \\
\text { підняття2 (геол.), } \\
\text { підйом1, підйом2, } \\
\text { сінопідіймач, сінопід- } \\
\text { німач, стеблепіднімач }\end{array}$ & $\begin{array}{l}\text { піднімальний, підій- } \\
\text { мальниц̆, підйом- } \\
\text { ний1а, піднятиц̆, } \\
\text { підійнятиц̆, підніма- } \\
\text { ючий }\end{array}$ & $\begin{array}{l}\text { попіднімати, попі- } \\
\text { діймати, піднятися, } \\
\text { підійнятися / підні- } \\
\text { матися, підійматися }\end{array}$ \\
\hline $\begin{array}{l}\text { a) возити } \\
\text { угору ліфтом, } \\
\text { підйомником }\end{array}$ & $\begin{array}{l}\text { піднімання, підій- } \\
\text { мання, підняття1, } \\
\text { підйом1, підйом6, } \\
\text { підйомник (техн.) }\end{array}$ & $\begin{array}{l}\text { піднімальниц̆, підій- } \\
\text { мальний, підйом- } \\
\text { ний1а, піднятий, } \\
\text { підійнятици, підніма- } \\
\text { ючий }\end{array}$ & $\begin{array}{l}\text { попіднімати, попі- } \\
\text { діймати, піднятися, } \\
\text { підійнятися / підні- } \\
\text { матися, підійматися }\end{array}$ \\
\hline
\end{tabular}

Своєрідність дієслова як однієї з центральних частин мови виявляється насамперед у компонентному складі його СП. Кількісний та якісний параметри конкретних СП дієслів, як відомо, залежать від лексичних і семантико-граматичних особливостей вершинного слова, його структури, семантико-синтаксичних зв'язків, активності та сфери функціонування. Тому важливо проаналізувати твірні слова за цими параметрами. На думку Н.Ф. Клименко, важливими критеріями для дослідника $є$ рубрикація лексичних значень та відповідне їх ремаркування в словнику (Клименко та ін., 1982, с. 101). У результаті аналізу твірних багатозначних префіксальних дієслів зі значенням «переміщення вгору» на основі характеру значення виділено дві групи. До першої групи відносимо ті твірні префіксальні дієслова, в яких значення «переміщення вгору» є основним: підняти, підійняти / піднімати, підіймати 1,a,2,a,б,в,3,a; підкинути / підкидати, підкидувати1; підтягти, підтягнути / підтягати, підтягувати1а; підстрибувати1; підскочити / підскакувати1; зійти / схо́дити, зіхо́дити1; підвищити / підвищувати1 та 
ін. Другу групу складають ті дієслова, в яких це значення $є$ неосновним: підсунути / підсувати, підсовувати 2а; вивезти / виво́зитиза; підлетіти / підлітати3; занести / зано́сити3; підвести / підводити7; знести / зносити 5 та ін. Вторинність деяких лексичних значень [...], за словами Н. Ф. Клименко, обмежує реалізацію словотвірних значень у всіх класах слів - іменниках, прикметниках, дієсловах (Клименко та ін., 1982, с. 128), що підтверджують і наші спостереження, пор.:

підкинути / підкидати, підкидувати1 - підкидання, підкинення, підкидач, підкиданици, підкидниц̆, підкинений, підкинутици, підкинутися / підкидатися, підкидуватися, навикидати, попідкидати;

підтягти, підтягнути / підтягати, підтягувати1а - підтягання, підтягнення, підтягування, підтягач, підтяжка, підтягнений, підтягнутий, підтягуваний, підтягтися / підтягатися, підтягуватися, навитягати (розм.), попідтягати;

підсунути / підсувати, підсовувати 2а - підсування, підсунення, підсунутий;

вивезти / виво́зитиза - вивезення, вивіз1, вивіз3 (діал.), вивозка, вивезений, повивозити.

Таблиця 2. Залежність кількості похідних від рубрикації значень

\begin{tabular}{|c|c|c|c|c|c|c|}
\hline $\begin{array}{c}\text { Рубри- } \\
\text { кація } \\
\text { значення }\end{array}$ & $\begin{array}{c}\text { К-сть } \\
\text { твірних }\end{array}$ & $\begin{array}{c}\text { У \% до } \\
\text { загальної } \\
\text { к-сті }\end{array}$ & $\begin{array}{c}\text { Кількість } \\
\text { дериватів } \\
\text { у СП }\end{array}$ & $\begin{array}{c}\text { Середня } \\
\text { кількість } \\
\text { дериватів } \\
\text { в одній } \\
\text { СП }\end{array}$ & $\begin{array}{c}\text { К-сть } \\
\text { нульових } \\
\text { СП }\end{array}$ & $\begin{array}{c}\text { у \% до } \\
\text { к-сті } \\
\text { твірних }\end{array}$ \\
\hline 1 & 31 & 50,8 & 101 & 3,3 & 11 & 18,0 \\
\hline 2 & 11 & 18,0 & 52 & 4,8 & 1 & 1,6 \\
\hline 3 & 9 & 14,8 & 27 & 3,0 & 2 & 3,3 \\
\hline 4 & 2 & 3,3 & 2 & 1,0 & - & - \\
\hline 5 & 2 & 3,3 & 4 & 2,0 & 1 & 1,6 \\
\hline 6 & 2 & 3,3 & 7 & 3,5 & - & - \\
\hline 7 & 3 & 4,9 & 10 & 3,3 & - & - \\
\hline 8 & 1 & 1,6 & - & - & 1 & 1,6 \\
\hline Всього & $\mathbf{6 1}$ & $\mathbf{1 0 0}$ & $\mathbf{2 0 3}$ & $\mathbf{3 , 3}$ & $\mathbf{1 6}$ & $\mathbf{2 6 , 1}$ \\
\hline
\end{tabular}

Відрізняються твірні дієслова і своїми функційно-стилістичними особливостями. Одні з них є стилістично нейтральними (підкинути / nidкидати, підкидувати1; підтягти, підтягнути / підтягати, підтягувати1а; 
підстрибувати1, підскочити / підскакувати1; зійти / схо́дити, зіхо́дити1; підвищити / підвищувати; підсунути / підсувати, підсовувати2а; вивезти / виво́зитиза; підлетіти / підлітатиз; занести / зано́ситиз та ін.), інші забарвлені (викарабкатися / викарабкуватися (розм.); викараскатися (розм.), викотитися / викочуватися (розм.); витеребитися² (фам.); вишкрябатися / вишкрябуватися (розм.); угнати (вгнати) / уганяти 2 (вганяти) 3 (розм.) тощо). Таке стилістичне маркування одних і належність до загальновживаної лексики інших аналізованих префіксальних дієслів детермінує їхній словотвірний потенціал (див. Клименко та ін., 1982, сс. 119, 128).

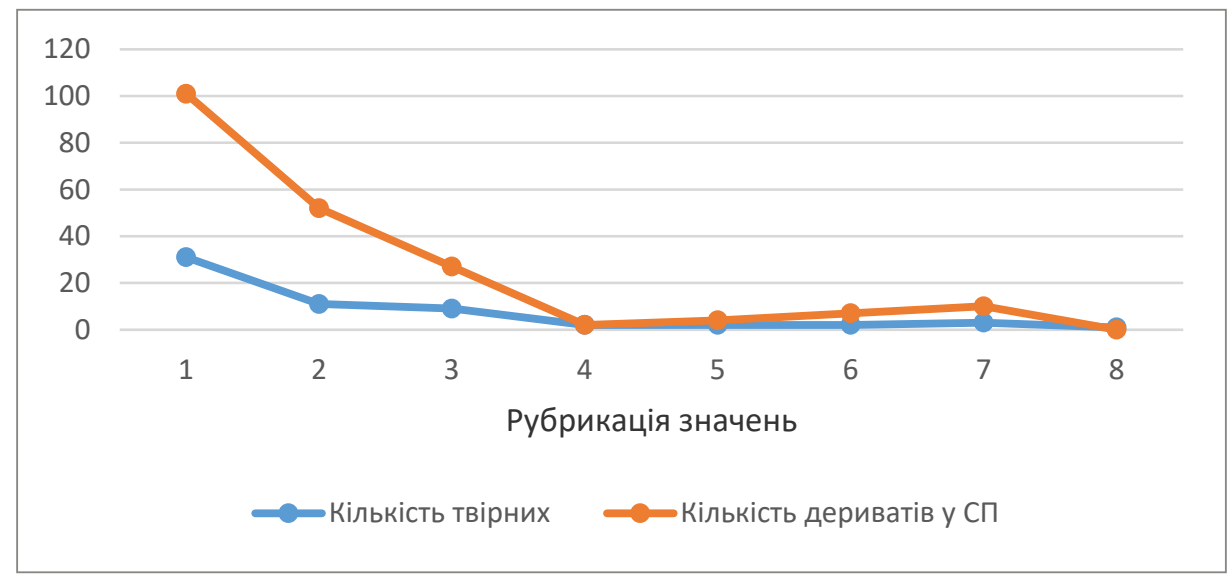

Рисунок 1. Залежність кількості похідних від рубрикації значень

За характером мотиваційних відношень похідні дієслова зі значенням «переміщення вгору» можна поділити на дві підгрупи:

1) більшість твірних аналізованої групи мотивовані дієсловами (вистрибнути / вистрибувати2; вибігти / вибігатиз; закинути / закидати 21б; збігти / збігати6; підлетіти / підлітатиз та ін.), що складає 96,6\%. Основними засобами їхнього творення $є$ префікси, найпродуктивнішими серед яких ви-, 3-, під- (виїхати / виїздити, виїжджатиз; витаскати / витаскувати1б (розм.); здійняти / здіймати1; підкинути / підкидати, підкидувати1 та ін.);

2) поодинокі твірні належать до відприкметникового походження (вивищити / вивищувати, підвищити / підвищувати1), які постали префіксально-суфіксальним способом (3,3\%). 
3 метою узагальнення і виявлення закономірності побудови СП усіх вилучених для аналізу префіксальних дієслів використовуємо запропонований Е. А. Земською термін «типова словотвірна парадигма», яку формують конкретні парадигми з однаковим набором дериваційних значень (Земська, 1992, с. 18). Опис типової СП твірних здійснюємо за блоками, кожен з яких становить собою сукупність словотвірних значень похідних певної частини мови. Для лексико-семантичної групи префіксальних дієслів зі значенням «переміщення вгору» характерна типова СП з чотирма частиномовними блоками дериватів: субстантивний, ад’єктвний, вербальний та адвербіальний.

Найбільше дериватів від префіксальних дієслів зі значенням «переміщення вгору» виявлено у складі субстантивного блоку типової СП. Цей блок досліджуваних дієслів становить велику за обсягом групу девербативів із розгалуженою системою значень. Характерною особливістю субстантивного блоку типової СП названих дієслів $€$ те, що більшість іiі членів - це суфіксальні транспозиційні деривати із словотвірним значенням «опредметнена дія» (60 девербативів, 33,3\%). Транспозиція дієслівної основи до іменникової пов'язана зі змінами, в результаті яких вихідне дієслово, зберігаючи в дещо модифікованому вигляді категорію виду, втрачає свої морфологічні категорії часу, способу та особи і водночас набуває іменникових граматичних категорій роду, числа й відмінка. Семантика дієслова в новоутвореному слові загалом збережена, але ступінь узагальнення зазнає змін у напрямку від конкретності (у дієсловах) до абстрактності (в іменниках) (Безпояско, 1987, с. 103).

Засобами вираження СЗ «опредметнена дія» $є$ суфікси -нн-(я), -енн-(я), Ø, -к-(а), -тт-(я), -ин-(и). Найбільшу групу складають іменники із суфіксом -нн-(я), -енн-(я): підсування, вивезення, вивищення, вилізання, витягання, витягнення, витягування, винесення, виплигування, закидання, злітання, підвищення, підвищування, підкидання, піднімання, підіймання, підстрибування та ін., напр.: Раптом підстрибування апарату припинились (О. Кацай). Це зумовлено тим, що суфікс-нн-(я), -енн-(я) в українській мові функціонально найактивніший, що забезпечило йому домінанту серед словотворчих суфіксів віддієслівних іменників зі словотвірним значенням «опредметнена дія» (Безпояско, 1987, с. 105). Немає жодних перешкод для утворення таких іменників, свідченням чого $є$ поодинокі іменники зі значенням «опредметнена дія», які не зафіксовано в тлумачних словниках: підкинення, підскакування (ВЗОССУЛ, 2003), що можна 
пояснити відставанням лексикографічного фіксування безперервних змін у словниковому складі української мови. Можна прогнозувати і подальшу появу таких дериватів. Так, Н. Ф. Клименко наголошує на зростанні кількості абстрактної лексики (назв абстрактних дій, процесів, станів, якостей, відношень) [...], збільшенні продуктивності словотворчих формантів, що виражають абстрактні поняття (типу -уванн(я), -анн(я), -енн(я), -изаці(я) [...]) (Клименко, 2008, с. 136).

Значно меншу групу похідних із цим словотвірним значенням утворюють іменники із Ø суфіксом: вивіз1, виїзд1, винос, вискік, зліт, знос nідйом1, підліт, підскок, підскік та ін., напр.: Ой, яким довжелезним видався Павлові отой нескінченний підйом на гору (М. Дашкієв). Виразниками словотвірного значення «опредметнена дія» $€$ також суфікси -к- (вивозка, підтяжка1), -тт- (підняття1), -ин- (сходиниз (рідко)), пор.: Потім океанограбічні експедиції в Червоному морі, підняття з дна Середномор'я затонулого ще до нашої ери грецького корабля (Л. Тендюк). Серед похідних із словотвірним значенням «опредметнена дія» виявлено поодинокі композити, які виникають на базі синтаксичної конструкції «дієслово + залежний іменник у непрямому відмінку»: суднопіднімання, суднопідіймання - піднімати, підіймати судно.

Однією з важливих ознак СП є їі глибина. Розгортання СП у глибину передбачає заповнення однієї й тієї ж семантичної позиції дериватами 3 різнозвучними формантами. Слів, що реалізують певне словотвірне значення, може бути одне або кілька. Серед досліджуваного матеріалу явище словотвірної синонімії найбільш поширене в межах іменників зі значенням «опредметнена дія», де зафіксовано від одного до чотирьох похідних (злітання, зліт; сходження, схід21, сходини3 (рідко); піднімання / підіймання, підйом1, підняття1, суднопідіймання / суднопіднімання та ін.), які можуть відрізнятися семантичними, стилістичними характеристиками, частотою і сферою вживання тощо.

Девербативи nomina actionis можуть виступати не тільки як синтаксичні, але й як лексичні деривати. Наприклад, при утворенні іменників із формантом Ø та -тт(я) поряд із процесуальним значенням реалізується і валентність місця (підйом2, вивіз3 (діал.), виїзд2, підняття2 (геол.), сxid22, сxid12), знаряддя (підйом6).

Мутаційний тип деривації у складі субстантивного блоку репрезентований словотвірними значеннями «знаряддя дії», «місце дії», «виконавець дії. Друге місце за кількістю одиниць посідають іменники із словотвірним 
значенням «знаряддя дії» (17, 9,4\%), засобами реалізації якого виступають суфікси -ач (піднімач (мед.), підвищувач, підтягач), Ø (підйом6, виїзд, сходи²), -к- (підтяжка2, сходки (діал.)), -ник (підйомник), -ц- (східиі), -ин- (сходина), -н- (сходні), напр.: На грузинському гірськолижному курорті Гудаурі несправність підйомника спричинила масове травмування відпочивальників («У Грузії», 2018). Словотвірне значення «знаряддя дії» реалізується і складними дериватами, утвореними за моделлю I+o(e)+Д+ач/ник (cmeблепіднімач, суднопідіймач, суднопідйомник, сінопідіймач, сінопіднімач) композити, в яких іменникова основа позначає об'єкт дії, можна описати за допомогою перифрази «те, за допомогою чого [...]», пор., стеблепіднімач - 'те, за допомогою чого піднімають стебла'. Напр.: Плавали кораблем по суші: через значні перепади висот Ельблонський канал (туристичне диво) має иілу систему суднопідйомників, схожих на фунікулер: корабель заходить у шлюз, прикріплюється до дерев'яної платформи на колесах і далі їде по рейках (Карпюк, 2012).

Поодинокими одиницями представлені іменники зі значенням «місце дії», утворені за допомогою суфіксів Ø (вивіз3 (діал.), виїзд2, nідйом2, сxід12, сxід22), -тт(я) (підняття2 (геол.)), та «виконавець дії» суфіксів -ач (підвищувач, підношувач, підкидач), -щик (піднощик). Напр.: Такі зелені й наӥвні, такі жовтороті чимчикують на схід, не знаючи, куди же ие вони чимчикують і що їх там чекає (І. Багряний). Деривати на позначення виконавця дії із суфіксом -ач на зразок підвищувач на практиці частіше зустрічаємо із словотвірним значенням «знаряддя дії». Таку ситуацію дослідники пояснюють перегрупуванням окремих значень всередині словотвірного типу, що зумовлене появою великої кількості засобів виробництва, машин і механізмів, що замінили працю людини (Олексенко, 2005, с. 83). Як наслідок зникла необхідність уживання лексеми з першим значенням. Напр.: Якщзо дитина нижча 1 метра 35 сантиметрів, то мусять використовуватися відповідні до ваги дитини, і установлені згідно з інструкціями виробника, сидіння немовляти, дитяче сидіння, підвищувач чи підвищувальна подушка (Лукеренко, 2011). Як бачимо, лексичні деривати в СП префіксальних дієслів представлені незначною кількістю. Це підтверджують і дослідники словотвірних гнізд дієслів руху. Зокрема М. П. Лесюк зазначає, що віддієслівні іменники з мутаційним словотвірним значенням творяться за допомогою різних моделей, однак, незважаючи на багатство словотворчих засобів, кількість їх порівняно з кількістю транспозиційних дериватів набагато менша, що 
можна пояснити меншою регулярністю і продуктивністю мутаційних моделей (Лесюк, 1987, с. 75).

Ад'єктивний блок типової СП префіксальних дієслів зі значенням «переміщення вгору» репрезентовано трьома словотвірними значеннями. До ад’єктивного блоку названих дієслів зараховуємо і дієприкметники. Щодо їх статусу в системі частин мови й досі не існує єдиного погляду. Традиційним є визначення дієприкметника як дієслівної форми, яка поєднує в собі дієслівні морфологічні значення часу, виду і стану з прикметниковими формами роду, числа і відмінка. Враховуючи те, що словотвірні характеристики дієприкметника подібні до словотвірних характеристик прикметника та що дуже часто дієприкметник піддається ад'єктивації, вважаємо доцільним розглядати дієприкметники серед ад’єктивів.

Значна кількість ад'єктивів об’єднана словотвірним значенням «ознака об'єкта за дією", засобами реалізації якого виступають суфікси -ен- (винесениц, витягнениц, закинениц, занесениц, підвищениц, підкинениц, зведениц̆, знесениц, підведениц̆, піднесений, підтягнениц̆), -ут- (витягнутиц̆, закинутий, підкинутий, підтягнутий), -т- (здійнятий, піднятий, підійнятий), -н- (підкиданий, підтягуваний). Напр.: На жпилі будинку Купецького зібрання, - де скликано урочистий мітинг, - був піднятий державний итандарт республіки Франиї: синьо-біло-червоний (Ю. Смолич).

Активно утворюються і девербативи із словотвірним значенням «призначений для того, на що вказує твірна основа». Найпродуктивнішим засобом вираження цього значення є суфікс -льн-, який приєднується до корелята недоконаного виду досліджуваних твірних дієслів: витягувальний (техн.), витягальний (спец.), підвищувальний (спец.), піднімальний, підіймальний, суднопідіймальний, суднопіднімальний. Декілька девербативів зафіксовано із суфіксом -н- (підйомний1а, підкидний). Напр.: На протилежному кіниі застиг, простягнувши величезну руку-стрілу, могутній підйомний кран (В. Суслов).

Словотвірне значення «ознака суб’єкта за дією» властиве поодиноким похідним прикметникам, засобами реалізації якого є суфікси -юч-, -яч-, -л- (піднімаючий, спливаючиц̆, сходячиц̆ (рідко), вилізлиц̆), окремі з яких на сьогодні є порушенням норми української мови.

У структуруванні СП префіксальних дієслів зі значенням «переміщення вгору» беруть участь і дієслова, які формують вербальний блок. 3-поміж них виділяємо префіксальні, суфіксальні і постфіксальні девер- 
бативи. Дієслівний блок СП досліджуваних дієслів репрезентують деривати із словотвірними значеннями «дистрибутивність дії», «виконуючи дію, переводити щось із стану об’єкта в стан суб'єкта», «кумулятивність дії», «однократність дії».

Префіксальні дієслова активно приєднують префікс по- і виражають значення «за допомогою дії, названої дієсловом, перемістити(ся) вгору всіх чи багатьох»: повискакувати, повистрибувати, повибігати, повибиратися, повивозити, повиїжджати, повилазити, повилізати, повитягувати, повитягати, попіднімати, попідіймати та ін., пор.: Тепер треба гарно все попіднімати (Ю. Яновський).

У результаті приєднання постфікса -ся до префіксальних дієслів руху виникають деривати зі словотвірним значенням «виконуючи дію, переводити щось зі стану об'єкта в стан суб'єкта»: вивищитися / вивищуватися; здійнятися / здійматися; піднятися / підніматися, підійматися; підвестися / підводитися. Напр.: Нам довелося облазити за ним більшість замкових споруд, піднятися до всіх чотирьох башт i здійснити неймовірно довгий підйом по спіральній драбині бергфріду (Д. Білий). Віддієслівні деривати з постфіксом -ся на зразок підтягтися, підтягнутися, закинутися / закидатися дослідники кваліфікують як такі, що мають дві паралельні мотивації. За словами В. А. Топіхи, такі девербативи належать до дієслівно-дієслівної словотвірної мотивації префіксально-постфіксальних дієслів, першою твірною основою яких $\epsilon$ лише безпрефіксні дієслова на -ся, а другою - тільки однопрефіксні дієслова доконаного виду (Топіха, 1998, сс. 14-15). 3 огляду на те, що мотивація таких девербативів префіксальними дієсловами можлива, їх розглядаємо в межах вербального блоку СП.

Зрідка префіксальні дієслова приєднують префікс на-, утворюючи девербативи із кумулятивним значенням (навикидати, навитягати (розм.), назво́дити), та суфікс -ну-, утворюючи девербативи зі значенням «однократність дії»: підстрибнути, вискокнути (рідко), напр.: 3бираються чабани, [...] спускаються у вогку колодязну глибінь, щеб вибирати звідти різну нечисть, мул, залізяччя [...]. Цілу купу, чорну смердючу, навикидають, наллють осторонь колодязя (О. Гончар). Іноді ій хотілося підстрибнути вгору, щоб послухати ближче ніжний спів очеретянок (О. Іваненко).

Адвербіальний блок типової СП аналізованих префіксальних лексем сформований словотвірним значенням «адвербіалізація дії» і представлений дериватами виплигом (діал.), вискоком, вистриби (рідко), вистрибом, 
вистрибием, підскоком (розм.), підстрибом (розм.), підстрибием (розм.). Напр.: 3 ними юрбою, з вискоком, трохи не з вибриком, пішли молоді гості на парадовий прихід з улиці (І. Нечуй-Левицький).

Не зафіксовано похідних дериватів у СП дієслів: злинути / злинати1, заплигнути / заплигувати, вишкрябатися / вишкрябуватися (розм.), витеребитися² (фам.), викараскатися (розм.), викарабкатися / викарабкуватися (розм.), видряпатися / видряпуватисяl,a, видертися, видратися / видиратися2, вигулькнути / вигулькувати1 (розм.), вибігти / вибігати3, вийти / виходити4, угнати (вгнати) / уганяти (вганяти)3 (розм.) та ін., тобто їхні СП виявилися нульовими (23,3\%), що зумовлено в основному стилістичним маркуванням твірних.

Таблиця 3. Кількісний розподіл за частинами мови

\begin{tabular}{|l|c|c|}
\hline \multicolumn{1}{|c|}{ Частини мови } & кількість & $\mathbf{\%}$ \\
\hline іменники & 87 & 48,3 \\
\hline прикметники & 33 & 18,3 \\
\hline дієслова & 52 & 28,8 \\
\hline прислівники & 8 & 1,6 \\
\hline Всього & $\mathbf{1 8 0}$ & $\mathbf{1 0 0}$ \\
\hline
\end{tabular}

Кількісний аналіз частиномовного складу аналізованих СП свідчить про те, що в їх структурі найчисельнішим є субстантивний блок, значно менше дериватів вербального та ад’єктивного блоків, поодинокі девербативи адвербіального блоку. Такий кількісний розподіл можна пояснити зокрема тим, що на відміну від безпрефіксних дієслів на позначення руху (див. Адамець, 2016) префіксальні дієслова реалізують свій потенціал в основному в іменникових дериватах.

Отже, в результаті аналізу префіксальних дієслів зі значенням «переміщення вгору» та їх похідних в українській мові можна зробити такі висновки:

1. Різні параметри твірних префіксальних дієслів детермінують породження дериватів із різними словотвірними значеннями: лексико-семантичні, структурні, функціонально-стилістичні, валентні тощо.

2. У структурі СП аналізованих ЛСВ префіксальних дієслів зі значенням «переміщення вгору» зафіксовано похідні різних частин мови, в межах яких виявлено такі словотвірні значення: «опредметнена дія», «знаряддя дії», «місце дії», «виконавець дії» - субстантивний блок, «ознака 
об’єкта за дією», «ознака суб’єкта за дією», «призначений для того, на що вказує твірна основа» - ад’єктивний блок, «дистрибутивність дії», «виконуючи дію, переводити щось із стану об’єкта в стан суб’єкта», «кумулятивність дії», «однократність дії» - вербальний блок та «адвербіалізація дії» адвербіальний блок. Префіксальні дієслова мають значний словотвірний потенціал насамперед на рівні субстантивного словотворення $(48,3 \%)$, менш регулярним є утворення дієслівних $(28,8 \%)$ і ад'єктивних $(18,3 \%)$ лексем і зовсім нерегулярним - утворення адвербіальних похідних.

3. Словотвірна активність ЛСВ зазначених дієслів реалізується здебільшого в синтаксичних дериватах: із 60 твірних у 35 (58,3\%) зафіксовано іменники $з$ опредметненим значенням. У семантиці окремих nomina actionis, крім процесуального, розвивається і конкретне значення, наприклад, значення місця (вивіз3 (діал.), виїзд2, підняття2 (геол.), схід22, cxid12), знаряддя (підйом6). У СП похідних зі значенням «опредметнена дія» зафіксовано від одного до чотирьох похідних з різними формантами (злітання, зліт; вивезення, вивіз1, вивозка; піднімання, підіймання, підйом1, підняття1, суднопіднімання, суднопідіймання та ін.).

4. Лексичні деривати в СП префіксальних дієслів представлені незначною кількістю - 27 (15\%). У 16 СП $(26,6 \%)$ зафіксовано девербативи зі значеннями «ознака суб'єкта за дією», «ознака об'єкта за дією», «призначений для того, на що вказує твірна основа», а в 31 твірного (51,6\%) - дієслова. Не зафіксовано похідних дериватів у СП 16 ЛСВ дієслів (26,2\%).

5. Способами словотворення виступають префіксація, суфіксація, постфіксація та основоскладання.

\section{Скорочення}

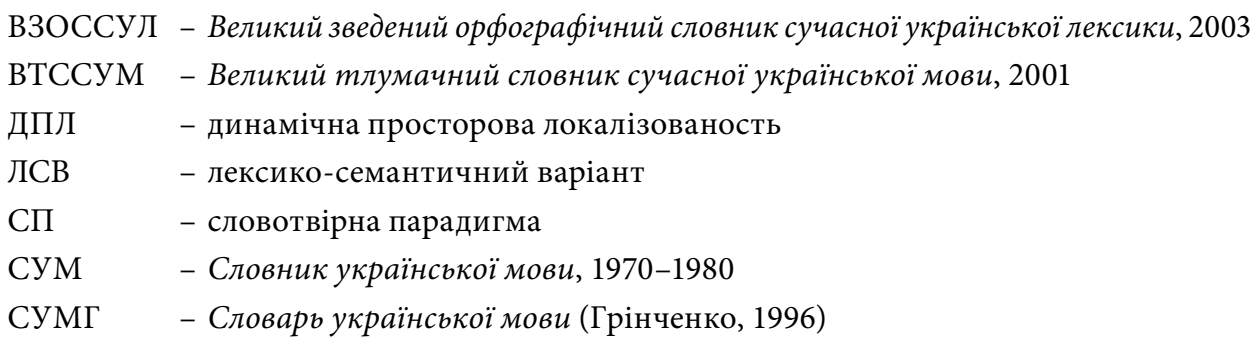




\section{Бібліографія}

Адамець, Н. В. (2016). Словотвірна парадигматика дієслів руху в сучасній українсвкій мові (Автореф. дис. канд. філол. наук). Прикарпатський нац. ун-т ім. В. Стефаника, Івано-Франківськ.

Безпояско, О. К. (1987). Морфеміка української мови. Київ: Наук. думка.

Бузашиова, К. (1987). Возможности и границы моделирования на уровне словообразовательных парадигм (pp. 14-19). In Г. П. Нещименко (Ed.), Сопоставительное изучение словообразования славянских языков. Москва: Наука.

Валюх, 3. О. (2005). Словотвірна парадигматика іменника в українській мові. Київ: АСМІ.

Великий зведений орфографічний словник сучасної украйнської лексики [ВЗОССУЛ]. (2003). Київ: ВТФ «Перун».

Великий тлумачний словник сучасної української мови [ВТССУМ]. (2001). Київ: ВТГ «Перун».

Грінченко, Б. Д. (1996). Словарь української мови [СУМГ] (Vols. 1-4). Київ: Наук. думка.

Грещук, В. В., Бачкур, Р. О., Джочка, І. Ф., \& Пославська, Н. М. (2007). Нариси з основоиентричної дериватологіï. Івано-Франківськ: Місто НВ.

Дідух, Н. (2004). Семантична структура параметричних прикметників. Вісник Львівського університету: Серія філологічна, 34(1), 159-167.

Земская, Е. А. (1992). Словообразование как деятельность. Москва: Наука.

Карпіловська, Є. А. (1999). Субіксальна підсистема сучасної украӥнської літературної мови: Будова і реалізація. Київ: УкрНДІПСК.

Карп’юк, В. (2012, July 16). Наталія Асатурян: Українськість, як не крути, поетична. Zaxid.net. Retrieved from https://zaxid.net/nataliya_asaturyan__ukrayinskist_yak _ne_kruti_poetichna_n1260131

Клименко, Н. Ф. (2008). Диференційні та інтеграційні процеси в лексиці та словотворенні сучасної української мови. Мовознавство, 2008(2-3), 136-147.

Клименко, Н. Ф. (2004). Словотвірна парадигма. In Українська мова: Енциклопедія (2nd ed., text rev., p. 619). Київ: Видавництво «Українська енциклопедія» ім. М. П. Бажана.

Клименко, Н. Ф., Пещак, М. М., \& Савченко, І. С. (1982). Формалізовані основи семантичної класифікації лексики. Київ: Наук. думка.

Ковалик, I. I. (1964). Словотвір іменників у сербо-лужицьких мовах. Львів.

Кушлик, О. П. (2015). Словотвірна парадигматика похідних дієслів в українській мові. Дрогобич: Коло.

Лесюк, М. П. (1987). Формування семантики віддієслівних іменників. Українське мовознавство, 14, 74-80.

Лукеренко, К. (2011, October 04). Ще раз про дитячі автокрісла. Українська правда: Блоги. Retrieved from https://blogs.pravda.com.ua/authors/lukerenko/4e8b675a90464/

Олексенко, В. П. (2005). Словотвірні категорії іменника. Херсон: Айлант.

Пославська, Н. (2011). Передумови вивчення дериваційного потенціалу дієслів: Науково-методичний аспект. Обріï, 2011(1), 81-87. 
Словник української мови [СУМ] (Vols. 1-11). (1970-1980). Київ: Наук. думка.

Соколова, С. О. (2003). Префіксальний словотвір дієслів у сучасній українській мові. Київ: Наук. думка.

Топіха, В. А. (1998). Множинність словотвірної мотивацї дієслів у сучасній украӥнській мові (Автореф. дис. канд. філол. наук). Ін-т української мови НАН України, Київ.

У Грузії зламаний підйомник «викидав» лижників, постраждали українці. (2018, March 16). Українська правда. Retrieved from https://www.pravda.com.ua/news/2018/03/16/7174804/

Buzássyová, K. (1973). Sémantická štruktúra slovenských deverbatív. Bratislava: Veda.

\section{Bibliography (Transliteration)}

Adamets', N. V. (2016). Slovotvirna paradyhmatyka diiesliv rukhu v suchasniŭ ukraïns'kiŭ movi (Summary of doctoral dissertation). Prykarpats'kyı̆ nats. un-t im. V. Stefanyka, IvanoFrankivs'k.

Bezpoiasko, O. K. (1987). Morfemika ukrä̈n'koï movy. Kyïv: Nauk. dumka.

Buzashiova, K. (1987). Vozmozhnosti i granitsy modelirovaniia na urovne slovoobrazovatel'nykh paradigm (pp. 14-19). In G. P. Neshchimenko (Ed.), Sopostavitel'noie izucheniie slovoobrazovaniia slavianskikh iazykov. Moskva: Nauka.

Buzássyová, K. (1973). Sémantická štruktúra slovenských deverbatív. Bratislava: Veda.

Didukh, N. (2004). Semantychna struktura parametrychnykh prykmetnykiv. Visnyk L'vivs'koho universytetu: Seriia filolohichna, 34(1), 159-167.

Greshchuk, V. V., Bachkur, R. O., Dzhochka, I. F., \& Poslavs'ka, N. M. (2007). Narysy $z$ osnovotsentrychnoï deryvatolohii. Ivano-Frankivs'k: Misto NV.

Hrinchenko, B. D. (1996). Slovar' ukraïns'koï movy [SUMH] (Vols. 1-4). Kyïv: Nauk. dumka.

Karpilovs'ka, I. A. (1999). Sufiksal'na pidsystema suchasnoï ukraïns'koï literaturnoï movy: Budova i realizatsiia. Kyïv: UkrNDIPSK.

Karp'iuk, V. (2012, July 16). Nataliia Asaturian: Ukraïns'kist', iak ne kruty, poetychna. Zaxid.net. Retrieved from https://zaxid.net/nataliya_asaturyan__ukrayinskist_yak_ne_kruti_poetichna _n1260131

Klymenko, N. F. (2004). Slovotvirna paradyhma. In Ukraïns'ka mova: Entsyklopediia (2nd ed., text rev., p. 619). Kyïv: Vydavnytstvo "Ukraïns'ka entsyklopediia” im. M. P. Bazhana.

Klymenko, N. F. (2008). Dyferentsiŭni ta intehratsiŭni protsesy v leksytsi ta slovotvorenni suchasnoï ukraïns'koï movy. Movoznavstvo, 2008(2-3), 136-147.

Klymenko, N. F., Peshchak, M. M., \& Savchenko, I. S. (1982). Formalizovani osnovy semantychnoï klasyfikatsiï leksyky. Kyïv: Nauk. dumka.

Kovalyk, I. I. (1964). Slovotvir imennykiv u serbo-luzhyts'kykh movakh. L'viv.

Kushlyk, O. P. (2015). Slovotvirna paradyhmatyka pokhidnykh diiesliv v ukraïns'kiŭ movi. Drohobych: Kolo. 
Lesiuk, M. P. (1987). Formuvannia semantyky viddiieslivnykh imennykiv. Ukraïns'ke movoznavstvo, $14,74-80$.

Lukerenko, K. (2011, October 04). Shche raz pro dytiachi avtokrisla. Ukraïns'ka pravda: Blohy. Retrieved from https://blogs.pravda.com.ua/authors/lukerenko/4e8b675a90464/

Oleksenko, V. P. (2005). Slovotvirni katehoriï imennyka. Kherson: Aŭlant.

Poslavs'ka, N. (2011). Peredumovy vyvchennia deryvatsiünoho potentsialu diiesliv: Naukovometodychnyı̆ aspekt. Obrii, 2011(1), 81-87.

Slovnyk ukraïns'koï movy [SUM] (Vols. 1-11). (1970-1980). Kyïv: Nauk. dumka.

Sokolova, S. O. (2003). Prefiksal'nyı̆ slovotvir diiesliv u suchasniŭ ukrä̈ns'kiı̆ movi. Kyïv: Nauk. dumka. Topikha, V. A. (1998). Mnozhynnist' slovotvirnoï motyvatsiï diiesliv u suchasniu ukraïns'kiı̆ movi (Summary of doctoral dissertation). In-t ukraïns'koï movy NAN Ukraïny, Kyïv.

U Hruziï zlamanyĭ pidǐomnyk "vykydav” lyzhnykiv, postrazhdaly ukraïntsi. (2018, March 16). Ukraïns'ka pravda. Retrieved from https://www.pravda.com.ua/news/2018/03/16/7174804/

Valiukh, Z. O. (2005). Slovotvirna paradyhmatyka imennyka v ukraïns'kiŭ movi. Kyïv: ASMI. Velyky̆ tlumachnyi slovnyk suchasnoï ukraïns'koï movy [VTSSUM]. (2001). Kyïv: VTH "Perun”. Velykyı̆ zvedenyı̆ orfohrafichnyı̆ slovnyk suchasnoï ukraïns'koï leksyky [VZOSSUL]. (2003). Kyïv: VTF "Perun".

Zemskaia, E. A. (1992). Slovoobrazovaniie kak deiatel'nost'. Moskva: Nauka.

\section{Prefixed Verbs with the Meaning 'move upwards' in the Structure of the Verbal Derivational Paradigm in the Ukrainian Language}

\section{Summary}

This article presents an analysis of the content and structural-semantic peculiarities of derivative prefixed verbs with the meaning 'move upwards'. As established, the verbs under consideration are characterised by twelve derivative meanings ('materialised action', 'means of action', 'place of action', 'doer of action', 'peculiar feature of the object of action', 'peculiar feature of the subject of action', 'the aim implied in the derivative stem', 'distributive character of action', 'causing transformation of an object into a subject by way of action', 'cumulative character of action', 'situational character of action', 'adverbalisation of action'), which can be separated into four part-of-speech blocks: substantive, adjective, verbal and adverbial. It has also been established that the analysed words first and foremost realise the derivative 
potential at the level of substantive word formation; verbal and adjectival derivations can be considered less regular; and adverbial derivatives are the most irregular ones.

\section{Czasowniki przedrostkowe o znaczeniu 'przemieszczać ku górze' w strukturze paradygmatu słowotwórczego czasowników w języku ukraińskim}

\section{Streszczenie}

Artykuł przedstawia analizę treści i osobliwości strukturalno-semantycznych czasowników przedrostkowych o znaczeniu 'przemieszczać ku górze'. Jak ustalono, wykazują one dwanaście znaczeń pochodnych: 'dokonana czynność', 'środki działania', 'miejsce czynności', 'wykonawca czynności', 'szczególna cecha przedmiotu czynności', 'szczególna cecha podmiotu czynności', 'cel implikowany w rdzeniu słowotwórczym', 'spowodowanie za sprawą czynności przemiany przedmiotu w podmiot', 'dystrybutywny charakter czynności', 'kumulatywny charakter czynności', 'sytuacyjny charakter czynności', 'adwerbializacja czynności'. Znaczenia te można podzielić na cztery bloki: rzeczownikowy, przymiotnikowy, czasownikowy i przysłówkowy. Ustalono również, że analizowane słowa realizują potencjał derywacyjny przede wszystkim w zakresie rzeczownikowym; derywaty czasownikowe i przymiotnikowe można uznać za mniej regularne, zaś przysłówkowe - za najbardziej nieregularne.

Keywords: word-building paradigm; word-building potential; word-building meaning; deverbative; word-building formant

Słowa kluczowe: paradygmat słowotwórczy; potencjał słowotwórczy; znaczenie słowotwórcze; derywat odczasownikowy; formant słowotwórczy

Liubomyr V.Sehin, Donbas State Pedagogical University, Slovyansk

ORCID: https://orcid.org/0000-0003-1966-0773

Correspondence: lyubomyr137@gmail.com

The preparation of this article was financed by the author.

Competing interests: The author declares that he has no competing interests. 